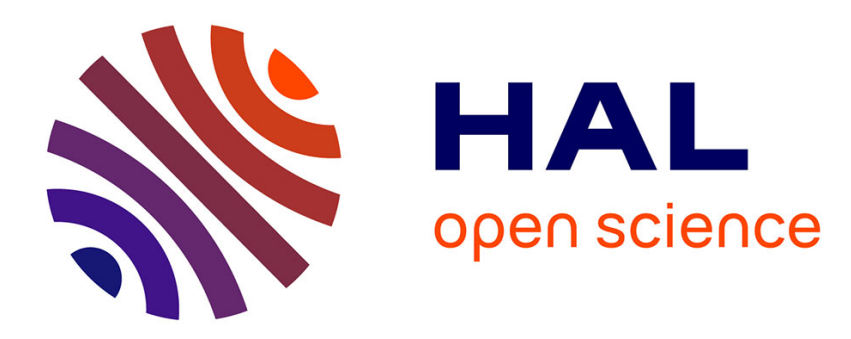

\title{
A New Fragment of P. Fouad inv. 267A: The PSI inv. 2006
}

\author{
Anne Tihon, Jean-Luc Fournet
}

\section{To cite this version:}

Anne Tihon, Jean-Luc Fournet. A New Fragment of P. Fouad inv. 267A: The PSI inv. 2006. Journal for the History of Astronomy, 2016, 47 (4), pp.355 - 358. 10.1177/0021828616666599 . hal-01597725

\section{HAL Id: hal-01597725 \\ https://hal.science/hal-01597725}

Submitted on 29 Sep 2017

HAL is a multi-disciplinary open access archive for the deposit and dissemination of scientific research documents, whether they are published or not. The documents may come from teaching and research institutions in France or abroad, or from public or private research centers.
L'archive ouverte pluridisciplinaire HAL, est destinée au dépôt et à la diffusion de documents scientifiques de niveau recherche, publiés ou non, émanant des établissements d'enseignement et de recherche français ou étrangers, des laboratoires publics ou privés. 


\section{A New Fragment of P. Fouad inv. 267A: The PSI inv. 2006}

Journal for the History of Astronomy 2016, Vol. 47(4) 355-358

(C) The Author(s) 2016

Reprints and permissions: sagepub.co.uk/journalsPermissions.nav DOI: $10.1177 / 0021828616666599$ jha.sagepub.com

@SAGE

\title{
Anne Tihon
}

Université Catholique de Louvain, Belgium

\section{Jean-Luc Fournet}

Collège de France, France

\begin{abstract}
This paper presents a new fragment of the astronomical papyrus P. Fouad inv. 267A, published by Jean-Luc Fournet and Anne Tihon, Conformément aux observations d'Hipparque: le Papyrus Fouad inv. 267A. Annex by Raymond Mercier (Publications de I'Institut Orientaliste de Louvain 67, 2014). This fragment preserved in Florence, PSI inv. 2006, appears to be a small piece of $P$. Fouad, and the astronomical contents on the verso fit exactly with the data of $P$. Fouad 267A.
\end{abstract}

\section{Keywords}

Papyrus, ancient astronomy, Hipparchus, Ptolemy

In 2014, Jean-Luc Fournet and I, with the help of Raymond Mercier for some mathematical analysis, published an astronomical papyrus especially important for the history of ancient astronomy: P. Fouad inv. 267A. ${ }^{1}$ This papyrus, preserved in the papyrological collection of the Institut français d'archéologie orientale du Caire (IFAO), contains a fragment of an astronomical treatise dealing mainly with the longitude of the Sun, calculated according to three different years: the sidereal year of $365 \mathrm{~d} 1 / 4+1 / 102$, the "mean" or "regular" year of $365 \mathrm{~d} 1 / 4$, and the tropical year of $365 \mathrm{~d} 1 / 4-1 / 30<9>$. The unknown author, probably a teacher, takes an example in the night of 8-9 November A.D. 130 at 3 hours from midnight in or near Alexandria; he calculates the longitude of the Sun according to these three different years and gives parallel tables showing the data of the calculation, organized in chronological sections according to the Egyptian calendar (years of 365

\section{Corresponding author:}

Anne Tihon, 28 rue Ferme du Coq, B-I490 Court-St-Etienne, Belgium.

Email: anne.tihon@uclouvain.be 
days and Egyptian months): periods of 30,000 years, 7000 years, 25 years, single years, months, days, and hours. These calculations imply a geometrical model with an eccentric, similar to the Ptolemaic model. He refers to an observation of Hipparchus unknown elsewhere, the summer solstice of 26 June 158 B.C., and to the precession of the equinoxes.

The references to the observations of Hipparchus, the coordinated use of both sidereal and tropical years, the great periods of 30,000 and 7000 years, with precise parameters and the sophistication of the underlying tables, the rate of the precession of approximately $1^{\circ}$ in 78 years, the eccentric model, and the date of the example taken at the time of Ptolemy (A.D. 130) are all elements that throw light on an astronomical "Syntaxis" different from Ptolemy's work and corresponding to the highest scientific standards.

As soon as our book was published, Jean-Luc Fournet announced the publication to his colleagues among papyrologists; one of them, Marco Stroppa, turned his attention to a fragment of a papyrus preserved in Florence, PSI inv. 2006, which seemed to be written by the same hand as P. Fouad. Indeed the photo of the fragment showed immediately that the verso was due to the same scribe as P. Fouad and that the astronomical content was part of our treatise. More precisely, the PSI inv. 2006 is nothing other than a small piece of the same folio as P. Fouad. Unfortunately, this discovery came too late to be included in our publication, but thanks to the courtesy of Guilio Bastianini, our edition and analysis of this fragment will appear in vol. XVII of the Papiri della Società Italiana, under no. 1674 .

As just said, this small fragment $(5 \mathrm{~cm} \times 5.8 \mathrm{~cm})$ belongs to the same folio as P. Fouad but gives some new pieces of information: the recto contains four lines in another handwriting (or style) that have no obvious relationship with the text of the verso (i.e. the astronomical treatise): they seem to be of astrological content. We could have the end of an astrological text beginning on previous pages of the codex and ending on this page. We will not go into further details about these four lines, but we mention them because of the palaeographical data they give to date this codex: they are written in the so-called Severe style which reached its peak during the third century A.D. So it is tempting to date this codex to this century rather than to the preceding one - as we did hesitantly in the edition of the P. Fouad. As a result, this codex was probably a miscellaneous codex gathering various astrological and astronomical texts, among which one was a treatise composed by a teacher in astronomy who lived in the second century A.D. and whose beginning is preserved by P. Fouad and PSI inv. 2006 verso. ${ }^{2}$

Verso, translation ${ }^{3}$

1 .

2. my table of ascensions

3. ... Hipparchus ... observations

4. from solstices to solstices

5. according to the solar anomaly

6. determined degrees $15\left[.^{\circ 4}\right.$

7. sidereal $154^{\circ} 33^{\prime} 53^{\prime \prime}$ subtract

8. hourly motion

9. .. ${ }^{\circ} 21$ remainder determined 


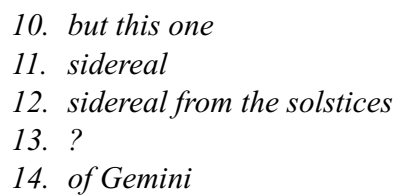

All the data of this fragment, as well as the specific astronomical terminology, can be found in P. Fouad: a table of ascensions (ảv $\left.\alpha \varphi \circ \rho \iota \kappa o ̀ v, v^{\circ} 8\right)$, Hipparchus and his observations $\left(\mathrm{r}^{\circ} 7,9-11\right)$, the tropical longitude (å $\pi$ ò $\left.\tau \rho o \pi \tilde{\omega} v, \mathrm{r}^{\circ} 7, \mathrm{v}^{\circ} 6\right)$, sidereal longitude

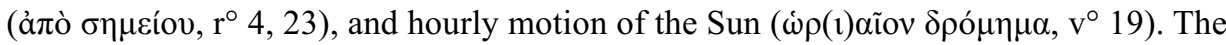

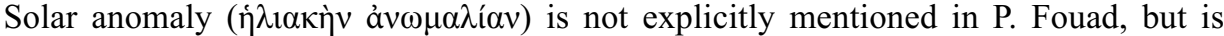
implied by the text which explains the corresponding correction. The number which appears at line 7 of PSI 2006, 154;33,53 ${ }^{\circ}$, differs only by 1 second from the sidereal longitude given by the sum of the numbers of tab. 1 of P. Fouad at the bottom of the recto $\left(153 ; 33,52^{\circ}, \mathrm{r}^{\circ} 32\right)$. The difference of $0 ; 0,1^{\circ}$ is easy to explain since the number written for 20 days of the Egyptian month Choiak $\left(18 ; 43,34^{\circ}\right)$ seems to be a mistake for $18 ; 43,35^{\circ}$ (see calculation in Fournet-Tihon, p. 77). The number of PSI, line 9, could be $14 ; 21^{\circ}$, which is the tropical longitude given in P. Fouad (ibidem, p. 97), although this reconstitution is rather uncertain from the palaeographical point of view. Finally, the mention of Gemini, PSI, line 14, could correspond to the apogee which we suggest was placed at Gemini $7^{\circ}\left(67^{\circ}\right)$ for tropical longitude and at Gemini $15^{\circ}\left(75^{\circ}\right)$ for sidereal longitude (ibidem, p. 105).

Despite the brevity of this fragment, one can see that the data given in PSI, $\mathrm{v}^{\circ}$, could be placed at the beginning of the verso of P. Fouad. The recto ends with the three tables giving the three mean longitudes, while the verso starts with the conversion of seasonal hours into equinoxial hours. In between one expects to find

- The calculation of the true positions (P. Fouad vo, 6-7), which is suggested by the solar anomaly of PSI, 5 and the word $\delta 1 \varepsilon v \kappa \rho \imath \eta \eta \mu \varepsilon v \varepsilon$, "determined" of PSI, 6;

- An announcement of the correction of time with help of a table of ascensions (PSI, 2);

- Some explanation about how to pass from sidereal longitude to tropical longitude or conversely (PSI,12?);

- A calculation implying the hourly motion of the Sun (PSI, 8), perhaps a readjustment of the solar longitude for the corrected hours - the passage of P. Fouad, $\mathrm{v}^{\circ}$ 19 , involving the hourly motion of the Sun remains unexplained because of the extreme deterioration of the papyrus;

- Information about the position of the solar apogee, which was required for finding the true positions.

Of course, on the strength of such meagre information, the logical development of the account is not altogether clear, and one regrets not having more precise information, for example, about the Solar apogee or on the correction of anomaly. But it is a real stroke of luck to have found another piece of this very important papyrus, and we are very grateful to the Italian papyrologists who enabled us to know and to study it. 


\section{Notes on Contributors}

Anne Tihon is Professor Emerita of the Université Catholique de Louvain, Louvain-la-Neuve, Belgium. She taught Byzantine History and Civilization, Byzantine Texts, History of Science in Antiquity, Greek Palaeography, and Methodology of the Edition of Ancient Texts. She has made critical editions of the commentaries of Theon of Alexandria on Ptolemy's Handy Tables, several editions of Byzantine astronomical texts, and with Jean-Luc Fournet, an edition and analysis of the astronomical papyrus P. Fouad inv. 267A. She is now working, with Raymond Mercier, on a critical edition of Ptolemy's Handy Tables.

Jean-Luc Fournet was a Member of the Centre national de la recherche scientifique (CNRS) (1996-2004) and Professor of papyrology at the Ecole Pratique des Hautes Etudes (2004-2015). He is now Professor at the Collège de France, holding the chair "Culture écrite de l'Antiquité tardive et papyrologie byzantine." He is a specialist in late antique papyrology and culture.

\section{References}

1. J.-L. Fournet and A. Tihon, Conformément aux observations d'Hipparque: le Papyrus Fouad inv. 267A. Annex by Raymond Mercier (Publications de l'Institut Orientaliste de Louvain 67) (Louvain-la-Neuve: supprimer Raymond Mercier, 2014). Reviews in Almagest V, 2, 128-130 (E. Nicolaides); Archiv für Papyrusforschung 62/1 (2016), 203-207 (A. Jones); A. Jones, "Unruly Sun: Solar Tables and calculations in the Papyrus P. Fouad 267A," Journal for the History of Astronomy, 47(1), 2016, pp. 76-79.

2. This codicological description is due to J.-L. Fournet.

3. Diacritical signs are not reproduced here.

4. $\rho v[]:. 153^{\circ}$ or $154^{\circ}$, see discussion infra.

5. à $\mathrm{xò} \sigma \eta \mu(\varepsilon)$ íov "from a point" is the expression used for the sidereal longitude : see FournetTihon, 111-113. The same words are found at lines 11 and 12. 